\title{
Actigard Increases Fungicide Efficacy Against Tobacco Blue Mold
}

\author{
J. A. LaMondia, The Connecticut Agricultural Experiment Station, Valley Laboratory, Windsor 06095
}

\begin{abstract}
LaMondia, J. A. 2008. Actigard increases fungicide efficacy against tobacco blue mold. Plant Dis. 92:1463-1467.

Blue mold, caused by Peronospora tabacina, can be economically damaging to cigar wrapper tobacco (Nicotiana tabacum). We evaluated acibenzolar-S-methyl (ASM) as Actigard 50WG alone and in combination with a standard fungicide program for efficacy against blue mold on shade-grown cigar wrapper tobacco in Windsor, CT. The standard fungicide program consisted of dimethomorph (Acrobat MZ or Forum) plus mancozeb (Dithane), alternated with azoxystrobin (Quadris), and applied at label rates on six occasions at 14-day intervals. Treated and untreated 5-by-5-m plots were replicated four times in 2003, 2004, 2005, 2006, and 2007. ASM treatments were applied alone or in combination with fungicides at the third, fourth, and fifth spray dates at rates ranging from 1.1 to $17.5 \mathrm{~g}$ a.i./ha. Disease was greatest in nontreated plots and reduced in all fungicide, Actigard, or combination treatments. The combination of three ASM applications at rates of $17.5 \mathrm{~g}$ a.i./ha down to $4.4 \mathrm{~g}$ a.i./ha with the standard fungicide program was more efficacious than either fungicides or ASM alone $(P<0.001)$ in reducing the number of blue mold lesions per plot or number of diseased leaves harvested. The combination of fungicides and low rates of ASM (2.2 or $1.1 \mathrm{~g}$ a.i./ha) was similar to either fungicides or ASM (17.5 g a.i./ha) applied alone. Combining low rates of ASM with fungicide applications greatly increased efficacy and marketable yield.
\end{abstract}

Additional keywords: disease control, systemic acquired resistance (SAR)

Cigar wrapper tobacco (Nicotiana tabacum L.) is a historic and important crop in the Connecticut River Valley of Connecticut and Massachusetts, with about 1,600 ha grown annually with an economic value of approximately $\$ 75$ million. The high value of the crop is only achieved if the leaves are of high quality and unblemished. The tobacco pathogen Peronospora tabacina D.B. Adam (P. hyoscyami f. sp. tabacina Skalický) causes a damaging leaf spot disease that can be economically devastating. The pathogen is not endemic but is periodically reintroduced into the northern tobacco-growing areas of the United States $(1,6)$. P. tabacina caused serious losses in 1979 and 1980, then was absent throughout much of the United States as a result of excellent control by metalaxyl fungicide (1). Metalaxyl-resistant P. tabacina was reported in Mexico in 1984 (14) and in the United States in 1991. The disease was present in Connecticut in late fall of 1996 (6) and has occurred each year since, resulting in tens of millions of dollars in losses.

Currently, blue mold is managed by repeated application of dimethomorph (Forum; BASF Corp., Research Triangle Park,

Corresponding author: J. A. LaMondia

E-mail: James.LaMondia@po.state.ct.us

Accepted for publication 7 July 2008.

doi:10.1094/PDIS-92-10-1463

(C) 2008 The American Phytopathological Society
NC), azoxystrobin (Quadris SC; Syngenta Crop Protection, Inc., Greensboro, NC), and mancozeb (Dithane DF; Dow AgroSciences, Indianapolis, IN) fungicides, which are two locally translaminar fungicides and one protectant fungicide, respectively. The lack of full systemic activity requires repeated application and complete plant coverage, which can be difficult to achieve $(7,8)$. Actigard 50 WG (acibenzolar-S-methyl; Syngenta Crop Protection, Inc.) induces tobacco plant resistance to a number of diseases, including blue mold $(2,11)$. In preliminary experiments, we determined that Actigard was effective at label rates but could cause some phytotoxicity and reductions in cured leaf quality (5). The objective of this research was to determine the efficacy of reduced rates of Actigard against blue mold, alone and in combination with other fungicides.

\section{MATERIALS AND METHODS}

Experiments were conducted in a clothcovered shade tobacco tent from 2003 to 2007 at the Connecticut Agricultural Experiment Station (CAES) Valley Laboratory Research Farm in Windsor, CT to determine the effects of Actigard application and rate alone or in combination with a commercial standard fungicide application program on blue mold leaf spot disease and healthy marketable leaf yield of cigar wrapper shade tobacco. Plots $5 \mathrm{~m}$ long by $5 \mathrm{~m}$ wide consisting of four planted rows were fertilized annually with cottonseed meal-based 10-8-10 (approximately $168 \mathrm{~kg} / \mathrm{ha}$ ) before planting in early
June. Ridomil Gold EC (mefoxenam; Syngenta Crop Protection, Inc.) at 1.2 liters/ha and Lorsban $4 \mathrm{E}$ at 7 liters/ha were tilled with a spring tooth harrow at the same time. Plots were planted with blue-moldsusceptible shade tobacco cv. 8212 in early June in four rows (15 plants per row, 30 $\mathrm{cm}$ apart within rows, with $39 \mathrm{~cm}$ between rows). Plots were side dressed with 10-810 at approximately $168 \mathrm{~kg} / \mathrm{ha}$ and cultivated in mid-June for total $\mathrm{N}$ of $336 \mathrm{~kg} / \mathrm{ha}$. Prowl 3.3 E (pendimethalin; BASF Corp.) was applied as a lay-by directed spray at 2.9 liters/ha using a 8004E nozzle at 175 $\mathrm{kPa}$ in late June. Plants were hand suckered and tied at the end of June and wrapped in early and mid-July.

Six applications of a standard fungicide program were applied to plots at 14-day intervals. The fungicide program consisted of dimethomorph (DM) plus mancozeb (MZ) alternated with azoxystrobin (AZ) with the sequence DM plus MZ, AZ, DM plus MZ, AZ, DM plus MZ, and AZ. DM was applied as Acrobat $50 \mathrm{WP}$ (BASF Corp.) in 2003 or Forum from 2004 to 2007 at rates of Acrobat at $224 \mathrm{~g} / \mathrm{ha}(112 \mathrm{~g}$ a.i./ha) or Forum at $219 \mathrm{ml} / \mathrm{ha}(110 \mathrm{~g}$ a.i./ha) at the first and last spray dates and Acrobat at $224 \mathrm{~g}$ a.i./ha or Forum at $220 \mathrm{~g}$ a.i./ha for the other application dates. MZ (Dithane) was used as a mixing partner at a rate of $800 \mathrm{~g}$ a.i./ha for all DM applications. AZ (Quadris) was applied at a rate of $249 \mathrm{~g}$ a.i./ha at all applications. Acibenzolar-S-methyl (ASM) was applied as Actigard three times in combination with Acrobat, Forum, or Quadris at rates ranging from 2.2 to $35.0 \mathrm{~g}$ of product (1.1 to $17.5 \mathrm{~g}$ a.i./ha) on the third, fourth, and fifth spray dates. There were four replicate plots of each treatment arranged in a randomized block design. ASM was applied three times at sprays three, four, and five.

Fungicide sprays were applied to the two inside plot rows using piston-pump backpack sprayers at 175 to $200 \mathrm{kPa}$ in 225 liters/ha (first spray date), 450 liters/ha (second spray), and 900 liters/ha (sprays three through six) of water to achieve coverage of spray rows. The two outside rows were unsprayed borders in each plot. Ripe leaves were picked on six weekly occasions, three leaves from each plant, and blue mold lesions counted on picked leaves for all plants in the two spray rows. The number of lesions per plot or per plant on picked leaves and number of healthy leaves (no visible lesions) per plot were recorded for each picking. Border row plants were not picked and severe disease levels typically occurred in the unsprayed 
borders of all plots. Counts of leaf lesions were $\log$ transformed for statistical analysis to stabilize variance and data were analyzed by analysis of variance. Means were separated by the protected Fisher's least significant difference multiple comparison test.

2003 Field experiment. Transplants were set into field plots on 9 June 2003 and treatments were applied on 26 June, 10 and 25 July, 8 and 21 August, and 5 September. Three ripe leaves were harvested and blue mold evaluated on each of five dates: 26 August and 3, 9, 16, and 25 September. The number of lesions were counted for the first three evaluations and number of healthy marketable (nonsymptomatic) leaves counted for the final two evaluations. Ten arbitrarily chosen leaves with blue mold lesions per plot were collected and the numbers of lesions per leaf were counted. Blue mold was first observed on the research farm on 18 August 2003.

2004 Field experiment. Transplants were set into field plots on 4 June 2004 and treatments were applied on 17 June, 2,
10, and 30 July, and 14 and 25 August. Three ripe leaves were harvested and blue mold evaluated on each of six dates: 25 and 31 August and 7, 14, 21, and 28 September. The numbers of lesions were counted and number of healthy marketable (nonsymptomatic) leaves counted for all evaluations. Blue mold was first observed on the research farm on 23 August 2004.

2005 Field experiment. Transplants were set into field plots on 9 June 2005 and treatments were applied on 30 June, 14 and 28 July, 11 and 25 August, and 14 September. Three ripe leaves were harvested and blue mold evaluated on each of six dates: 5 and 23 August, 20 September, and 4,11 , and 20 October. The numbers of lesions were counted and number of healthy marketable (nonsymptomatic) leaves counted for all evaluations. Blue mold was first observed on the research farm very late in the season on 30 September 2005 .

2006 Field experiment. Transplants were set into field plots on 12 June 2006 and treatments were applied on 30 June, 13 and 28 July, and 11, 24, and 31 August.

Table 1. Effects of fungicide and acibenzolar-S-methyl (ASM) applications on blue mold development in shade-grown cigar wrapper tobacco (2003)

\begin{tabular}{lccc}
\hline & \multicolumn{3}{c}{ Blue mold development $^{\mathbf{y}}$} \\
\cline { 2 - 4 } Applications (ASM g a.i./ha) & Lesions/plant & Marketable leaves & Lesions/diseased leaf \\
\hline Nontreated control & $71.9 \mathrm{e}$ & $0.0 \mathrm{e}$ & $53.5 \mathrm{f}$ \\
Fungicide alone & $2.4 \mathrm{c}$ & $1.5 \mathrm{c}$ & $16.3 \mathrm{~d}$ \\
ASM alone (4.4) & $8.0 \mathrm{~d}$ & $0.7 \mathrm{~d}$ & $27.5 \mathrm{e}$ \\
Fungicide + ASM (17.5) & $0.1 \mathrm{a}$ & $4.7 \mathrm{a}$ & $3.1 \mathrm{a}$ \\
Fungicide + ASM ( 8.8) & $0.1 \mathrm{a}$ & $3.6 \mathrm{~b}$ & $6.9 \mathrm{~b}$ \\
Fungicide + ASM (4.4) & $0.3 \mathrm{~b}$ & $3.1 \mathrm{~b}$ & $8.2 \mathrm{bc}$ \\
Fungicide + ASM ( 2.2) & $0.5 \mathrm{~b}$ & $3.1 \mathrm{~b}$ & $8.9 \mathrm{c}$ \\
$P \leq$ & 0.001 & 0.001 & 0.001 \\
\hline
\end{tabular}

y Blue mold development was measured by the number of lesions per plant on the first three harvest dates (nine leaves total), the number of marketable nonsymptomatic leaves in harvests 4 and 5 (six leaves per plant), and lesions per diseased leaf in harvests 4 and 5. Numbers within a column followed by a common letter are not significantly different according to the protected Fisher's least significant difference multiple comparison test $(P \leq 0.05)$.

${ }^{\mathrm{z}}$ Six applications of fungicide or ASM (Actigard) at the listed rates at 14-day intervals. The fungicide program consisted of dimethomorph (Acrobat $50 \mathrm{WP}$ at 112 for the first application or $224 \mathrm{~g}$ a.i./ha for all others) alternated with azoxystrobin (Quadris at $249 \mathrm{~g}$ a.i./ha). ASM was applied three times at sprays 3,4 , and 5 .

Table 2. Effects of fungicide and acibenzolar-S-methyl (ASM) applications on blue mold development in shade-grown cigar wrapper tobacco (2004)

\begin{tabular}{|c|c|c|}
\hline \multirow[b]{2}{*}{ Applications (ASM g a.i./ha) $)^{\mathrm{z}}$} & \multicolumn{2}{|c|}{ Blue mold development ${ }^{y}$} \\
\hline & Lesions/plant & Marketable leaves \\
\hline Nontreated control & $443.5 \mathrm{~d}$ & $3.7 \mathrm{~d}$ \\
\hline Fungicide alone & $20.4 \mathrm{c}$ & $11.7 \mathrm{c}$ \\
\hline Fungicide + ASM (8.8) & $0.5 \mathrm{a}$ & $14.8 \mathrm{a}$ \\
\hline Fungicide + ASM ( 4.4) & $2.0 \mathrm{a}$ & $13.7 \mathrm{ab}$ \\
\hline Fungicide + ASM (2.2) & $9.1 \mathrm{bc}$ & $13.0 \mathrm{bc}$ \\
\hline Fungicide + ASM (1.1) & $18.3 \mathrm{bc}$ & $11.9 \mathrm{c}$ \\
\hline$P \leq$ & 0.001 & 0.002 \\
\hline
\end{tabular}

${ }^{\mathrm{y}}$ Blue mold development was measured by the number of lesions per plant and the number of marketable nonsymptomatic leaves over six weekly harvest dates (three leaves per plant per harvest date). Numbers within a column followed by a common letter are not significantly different according to the protected Fisher's least significant difference multiple comparison test $(P \leq 0.05)$.

${ }^{z}$ Six applications of fungicide or ASM (Actigard) at the listed rates at 14-day intervals. The fungicide program consisted of dimethomorph (Forum at $110 \mathrm{~g}$ a.i./ha for the first application or $220 \mathrm{~g}$ a.i./ha for all others) alternated with azoxystrobin (Quadris at $249 \mathrm{~g}$ a.i./ha). ASM was applied three times at sprays 3,4 , and 5 .
Three ripe leaves were harvested and blue mold evaluated on each of six dates: 17 , 22, and 30 August and 5, 12, and 20 September. The numbers of lesions were counted and number of healthy marketable (nonsymptomatic) leaves counted for all evaluations. Blue mold was first observed on the research farm on 7 August 2006.

2007 Field experiment. Transplants were set into field plots on 20 June 2007 and treatments were applied on 12 and 25 July, 7 and 22 August, and 5 and 19 September. Three ripe leaves were harvested and blue mold evaluated on each of six dates: 17, 23, and 31 August and 6, 12, and 21 September. The numbers of lesions were counted and number of healthy marketable (nonsymptomatic) leaves counted for all evaluations. Blue mold was first observed on the research farm on $16 \mathrm{Au}$ gust 2007. Linear regression of log ASM application rate and percent reduction in blue mold lesions compared with a nontreated control or fungicide-only treatment and comparison of lines for ASM treatments with and without fungicides was conducted using Statistix 9.0 (Analytical Software, Tallahassee FL).

\section{RESULTS}

2003 Field experiment. All treatments applied were effective in reducing blue mold compared with the nontreated control plots (Table 1). ASM alone applied three times at $4.4 \mathrm{~g}$ a.i./ha was intermediate between the standard fungicide spray program of six applications of DM and $\mathrm{MZ}$ alternated with AZ fungicides. The addition of three ASM applications to the standard fungicide program significantly reduced the number of lesions per plant and number of lesions per diseased leaf and increased the number of marketable leaves in the fourth and fifth harvests.

2004 Field experiment. Treatments applied were effective in reducing the number of blue mold lesions on harvested leaves and increasing marketable leaves harvested over the season compared with the nontreated control plots (Table 2). There were no differences between applications of fungicide alone and fungicide plus ASM at rates of 1.1 to $8.8 \mathrm{~g}$ a.i./ha. However, fungicide plus ASM treatments at $4.4 \mathrm{~g}$ a.i./ha or higher were more effective in reducing blue mold than the fungicide program alone or fungicide plus lower rates of ASM $(P<0.001)$. The addition of $\mathrm{ASM}$ at 4.4 or $8.8 \mathrm{~g}$ a.i./ha also increased the number of marketable leaves harvested over the season relative to the nontreated control and lower ASM rates.

2005 Field experiment. All fungicide and fungicide plus ASM treatments applied were effective in reducing the number of blue mold lesions per plant and increasing the number of marketable leaves harvested over the season compared with the nontreated control (Table 3). Disease first occurred late in the season and 
disease severity was lower than other years.

2006 Field experiment. All treatments applied were effective in reducing the number of blue mold lesions on harvested leaves and increasing marketable leaves harvested over the season compared with the nontreated control plots (Table 4). There were no differences in numbers of lesions per plant between applications of fungicide alone, ASM alone at $17.5 \mathrm{~g}$ a.i./ha, or fungicide plus ASM at rates of 1.1 to $2.2 \mathrm{~g}$ a.i./ha. Fungicide plus ASM treatments at $4.4 \mathrm{~g}$ a.i./ha or higher were more efficacious than the fungicide program alone or fungicide plus ASM at 1.1 or $2.2 \mathrm{~g}$ a.i./ha $(P<0.006)$. The addition of ASM at 4.4 or $8.8 \mathrm{~g} \mathrm{a.i} /$ ha also increased the number of marketable leaves harvested over the season relative to the nontreated control, ASM alone treatment, and lower ASM rates in combination with fungicide application.

2007 Field experiment. Four ASM rates $(0,1.1,4.4$, and $17.5 \mathrm{~g}$ a.i./ha) were applied alone or in combination with the standard fungicide program for management of tobacco blue mold (Table 5). The fungicide program alone was not particularly effective, despite a significant reduction in numbers of lesions per plant compared with the nontreated control. ASM application alone (three sprays only) at rates of 4.4 or $17.5 \mathrm{~g}$ a.i./ha resulted in fewer lesions per plant and greater numbers of marketable leaves than either the nontreated control or fungicide program alone (six sprays). ASM application (three sprays) alone at $1.1 \mathrm{~g}$ a.i./ha was not effective in controlling blue mold or increasing yields. However, all combinations of ASM application, at rates as low as $1.1 \mathrm{~g}$ a.i./ha, with the fungicide program resulted in superior disease control and increased numbers of nonsymptomatic marketable leaves harvested compared with the nontreated control or the fungicide program alone. The dose-response curve for ASM alone or in combination with the standard fungicide program is presented in Figure 1. ASM at rates of 1.1 to $17.5 \mathrm{~g}$ a.i./ha (applied alone) reduced blue mold lesion numbers by 30 to $85 \%$ when compared with the nontreated control (no ASM, no fungicide). When ASM was applied in combination with fungicides, the same rates reduced lesion numbers by 86 to $96 \%$ compared with the standard fungicide program. The dose-response line for ASM with fungicide was described by the equation $Y=17.96 X+42.19\left(R^{2}=0.99\right)$ and the line for ASM applied alone was $Y$ $=83.0 X+8.34\left(R^{2}=0.96\right)$. The slopes and intercepts for the two lines were different $(P<0.009$ and 0.05 , respectively $)$.

\section{DISCUSSION}

Blue mold is an explosive disease that can be economically devastating to Connecticut cigar wrapper tobacco lines where the tolerance to damage is very low. Curable cigar wrapper tobacco cultivars available with resistance to $P$. tabacina, and the climate and culture of shade tobacco are very conducive for disease. As a result, growers rely heavily on repeated applications of protectant and local-systemic fungicides to control the disease. Additional systemic management tools would be helpful in reducing losses. Systemic acquired resistance (SAR) is a systemic response biological or salicylic-acid-induced resistance (4). Actigard (ASM) is the first synthetic SAR chemical developed and labeled for use in the United States (13). The current label use rate for blue mold management in tobacco is $35 \mathrm{~g} / \mathrm{ha}(17.5 \mathrm{~g}$

Blue mold occurred in the Connecticut River Valley each year of these experiments and was first observed on the CAES Research Farm in August or September of each year. Levels of disease were severe in nontreated plots and in the unsprayed borrently, there are no commercially acceptthat activates plant genes turned on by a.i./ha).

der rows in four of the five years. Disease severity was lower in 2005 because the epidemic started late in the season (the last day of September). ASM applied alone was effective against blue mold in these experiments at rates of $17.5 \mathrm{~g}$ a.i./ha to as low as $4.4 \mathrm{~g}$ a.i./ha and in combination with fungicide at rates as low as $1.1 \mathrm{~g}$ a.i./ha. There was a linear relationship between ASM efficacy as measured by the reduction in leaf lesions and log Actigard rates in the absence of fungicides. Efficacy ranged from a 31 to $82 \%$ reduction in leaf lesions at rates of 1.1 to $17.5 \mathrm{~g}$ a.i./ha. When ASM was applied in combination with fungicides, however, the linear relationship had little slope because efficacy ranged from 86 to $96 \%$ over the same rates. It appears that low rates of ASM are much more effective in combination with fungicides than applied alone or when compared with fungicides applied without ASM. The mechanism of this synergistic interaction is unknown.

There are a number of reasons why SAR would be desirable in an integrated man-

Table 3. Effects of fungicide and acibenzolar- $S$-methyl (ASM) on blue mold development in shadegrown cigar wrapper tobacco (2005)

\begin{tabular}{|c|c|c|}
\hline \multirow[b]{2}{*}{ Applications (ASM g a.i./ha) ${ }^{\mathrm{z}}$} & \multicolumn{2}{|c|}{ Blue mold development ${ }^{y}$} \\
\hline & Lesions/plant & Marketable leaves \\
\hline Nontreated control & $62.6 \mathrm{~d}$ & $11.3 \mathrm{~b}$ \\
\hline Fungicide alone & $1.7 \mathrm{~b}$ & $17.6 \mathrm{a}$ \\
\hline Fungicide + ASM (8.8) & $0.2 \mathrm{a}$ & $17.9 \mathrm{a}$ \\
\hline Fungicide + ASM (4.4) & $1.0 \mathrm{ab}$ & $17.6 \mathrm{a}$ \\
\hline Fungicide + ASM (2.2) & $2.2 \mathrm{c}$ & $17.6 \mathrm{a}$ \\
\hline Fungicide + ASM (1.1) & $3.0 \mathrm{c}$ & $17.0 \mathrm{a}$ \\
\hline$P \leq$ & 0.001 & 0.001 \\
\hline
\end{tabular}

${ }^{\mathrm{y}}$ Blue mold development was measured by the number of lesions per plant and the number of marketable nonsymptomatic leaves over six weekly harvest dates (three leaves per plant per harvest date). Numbers within a column followed by a common letter are not significantly different according to the protected Fisher's least significant difference multiple comparison test $(P \leq 0.05)$.

${ }^{\mathrm{z}} \mathrm{Six}$ applications of fungicide and/or ASM (Actigard) at the listed rates at 14-day intervals. The fungicide program consisted of dimethomorph (Forum at $110 \mathrm{~g}$ a.i./ha for the first application or $220 \mathrm{~g}$ a.i./ha for all others) alternated with azoxystrobin (Quadris at $249 \mathrm{~g}$ a.i./ha). ASM was applied three times at sprays 3,4 , and 5 .

Table 4. Effects of fungicide and acibenzolar-S-methyl (ASM) on blue mold development in shadegrown cigar wrapper tobacco (2006)

\begin{tabular}{lccc}
\hline & \multicolumn{3}{c}{ Blue mold development $^{\mathbf{y}}$} \\
\cline { 2 - 4 } Applications (ASM g a.i./ha) & Lesions/plant & Marketable leaves & Lesions/diseased leaf \\
\hline Nontreated control & $762.4 \mathrm{~d}$ & $5.2 \mathrm{e}$ & $59.3 \mathrm{c}$ \\
Fungicide alone & $69.2 \mathrm{c}$ & $10.0 \mathrm{~d}$ & $8.4 \mathrm{~b}$ \\
ASM alone (17.5) & $37.6 \mathrm{bc}$ & $11.6 \mathrm{~cd}$ & $5.8 \mathrm{~b}$ \\
Fungicide + ASM (17.5) & $10.9 \mathrm{a}$ & $15.0 \mathrm{a}$ & $3.5 \mathrm{a}$ \\
Fungicide + ASM ( 8.8) & $15.0 \mathrm{a}$ & $14.6 \mathrm{ab}$ & $4.2 \mathrm{a}$ \\
Fungicide + ASM ( 4.4) & $28.8 \mathrm{~b}$ & $13.0 \mathrm{bc}$ & $5.4 \mathrm{ab}$ \\
Fungicide + ASM ( 2.2) & $55.8 \mathrm{bc}$ & $11.3 \mathrm{~cd}$ & $8.0 \mathrm{~b}$ \\
Fungicide + ASM (1.1) & $49.1 \mathrm{bc}$ & $11.0 \mathrm{~d}$ & $6.9 \mathrm{~b}$ \\
$P \leq$ & 0.001 & 0.001 & 0.001 \\
\hline
\end{tabular}

${ }^{y}$ Blue mold development was measured by the number of lesions per plant and the number of marketable nonsymptomatic leaves over six weekly harvest dates (three leaves per plant per harvest date) and lesions per diseased leaf. Numbers within a column followed by a common letter are not significantly different according to the protected Fisher's least significant difference multiple comparison test $(P \leq 0.05)$.

${ }^{\mathrm{z}}$ Six applications of fungicide or ASM (Actigard) at the listed rates at 14-day intervals. The fungicide program consisted of dimethomorph (Forum at $110 \mathrm{~g}$ a.i./ha for the first application or $220 \mathrm{~g}$ a.i./ha for all others) alternated with azoxystrobin (Quadris at $249 \mathrm{~g}$ a.i./ha). ASM was applied three times at sprays 3,4 , and 5 . 
agement program for control of blue mold in Connecticut wrapper tobacco. First, applied alone, the SAR activator ASM achieved significant control of blue mold as evidenced by these experiments and by other researchers $(2,11)$. In the current experiments, we report that ASM alone at three sprays of $17.5 \mathrm{~g}$ a.i./ha reduced lesions per plant by over $88 \%$ and increased marketable leaf harvest by $48 \%$ compared with the nontreated controls (averaged over years). Applications of ASM at $8.8 \mathrm{~g}$ a.i./ha (half the label rate) in combination with fungicides resulted in $99 \%$ control of leaf lesions and an $83 \%$ increase in leaf

harvest, a marked improvement over the fungicide program alone, which resulted in a $50 \%$ increase in marketable yields over the nontreated controls. Second, the systemic activity exhibited by SAR materials such as ASM is very desirable. Connecticut shade tobacco is grown at high plant densities of over 27,000 plants/ha each at a height of $3 \mathrm{~m}$ under cloth in a shadecovered tent, with each plant individually tied to a wire running over each row. This makes spray coverage extremely difficult and expensive (7). Third, the mode of action of SAR inducers is indirect and does not exert selection pressure on pathogens

Table 5. Effects of fungicide and acibenzolar-S-methyl (ASM) on blue mold development in shadegrown cigar wrapper tobacco (2007)

\begin{tabular}{|c|c|c|}
\hline \multirow[b]{2}{*}{ Applications (ASM g a.i./ha) $)^{z}$} & \multicolumn{2}{|c|}{ Blue mold development ${ }^{y}$} \\
\hline & Lesions/plant & Marketable leaves \\
\hline Nontreated control & $188.4 \mathrm{~d}$ & $1.0 \mathrm{e}$ \\
\hline Fungicide alone & $109.8 \mathrm{c}$ & $3.6 \mathrm{de}$ \\
\hline ASM alone (17.5) & $33.8 \mathrm{ab}$ & $8.8 \mathrm{bc}$ \\
\hline Fungicide + ASM (17.5) & $4.1 \mathrm{a}$ & $15.6 \mathrm{a}$ \\
\hline ASM alone ( 4.4) & $75.6 \mathrm{bc}$ & $5.6 \mathrm{~cd}$ \\
\hline Fungicide + ASM ( 4.4) & $10.9 \mathrm{a}$ & $12.7 \mathrm{ab}$ \\
\hline ASM alone (1.1) & $129.3 \mathrm{~cd}$ & $1.2 \mathrm{e}$ \\
\hline Fungicide + ASM (1.1) & $15.1 \mathrm{ab}$ & $12.7 \mathrm{ab}$ \\
\hline \multicolumn{3}{|l|}{ Factor $(P \leq)$} \\
\hline Fungicide & 0.001 & 0.001 \\
\hline ASM & 0.001 & 0.001 \\
\hline Interaction & $\mathrm{ns}$ & ns \\
\hline
\end{tabular}

${ }^{\mathrm{y}}$ Blue mold development was measured by the number of lesions per plant and the number of marketable nonsymptomatic leaves over six weekly harvest dates (three leaves per plant per harvest date). Numbers within a column followed by a common letter are not significantly different according to the protected Fisher's least significant difference multiple comparison test $(P \leq 0.05)$; ns $=$ not significant.

${ }^{\mathrm{z}}$ Six applications of fungicide or ASM (Actigard) at the listed rates at 14-day intervals. The fungicide program consisted of dimethomorph (Forum at $110 \mathrm{~g}$ a.i./ha for the first application or $220 \mathrm{~g}$ a.i./ha for all others) alternated with azoxystrobin (Quadris at $249 \mathrm{~g}$ a.i./ha). ASM was applied three times at sprays 3,4 , and 5 .

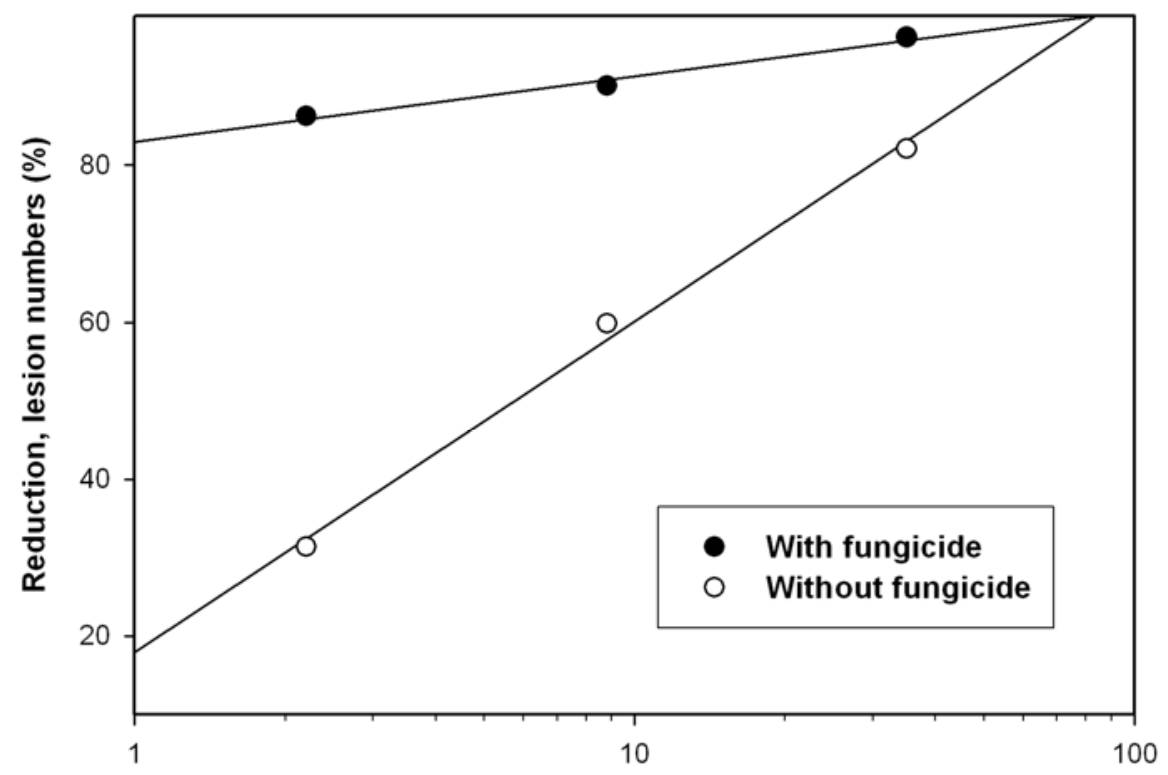

Actigard dosage (g 50\% formulation $\mathrm{ha}^{-1}$ spray $^{-1}$ )

Fig. 1. Effect of acibenzolar-S-methyl (ASM) application rate applied as Actigard alone or in combination with a fungicide program on efficacy as measured by the reduction in blue mold lesions compared with a nontreated control or fungicide-only treatment, 2007. to develop insensitivity, as may the currently used single-mode-of-action fungicides DM and AZ (12). Currently, MZ is used as a protectant mixing partner to help manage fungicide resistance but $\mathrm{MZ}$ is relatively ineffective against blue mold and can leave residues which may affect marketability. An SAR inducer such as ASM may be a more effective and desirable resistance-management alternative. Finally, the use of SAR elicitors, which have no direct antimicrobial activity and low toxicity, is environmentally benign in comparison to pesticide alternatives (12).

There may be a cost to the plant for inducing resistance, however (12,13). In previous research, we observed flecking and off-color cured leaves on shade tobacco with ASM at rates of $35 \mathrm{~g}$ a.i./ha (2x label rates) (5). Commercial evaluation of shade tobacco treated with ASM at $17.5 \mathrm{~g}$ a.i./ha over 2 years resulted in no detrimental effects or some reduced quality when ASM was applied to droughtstressed plants (unpublished data). We have not observed any negative impacts on cured leaves at rates lower than 17.5 ga.i./ha, although there was a slight tendency to early ripening with ASM at the $8.8 \mathrm{~g}$ a.i./ha rate in the experiments reported here (data not shown). These results are consistent with Csinos et al. (3), who observed that stunting was associated with physiological plant stress rather than simply the rate of ASM applied to plants. The synergistic interaction between fungicides and ASM should allow effective use of ASM at rates well below those which cause phytotoxic or leaf quality effects.

The results of the current study demonstrate that ASM alone (three sprays at rates of $4.4 \mathrm{~g}$ a.i./ha or higher) is efficacious against $P$. tabacina on susceptible tobacco under conducive conditions very favorable for disease. ASM at rates as low as $1.1 \mathrm{~g}$ a.i./ha in combination with a standard fungicide program can result in up to $94 \%$ control of lesions per plant and result in a $64 \%$ increase in the number of marketable unblemished leaves per plant compared with the nontreated control. The interaction of SAR initiators and fungicides to result in a synergistic effect against pathogens has been previously demonstrated. Molina et al. (10) reported that benzothiadiazole reduced the amounts of fungicide required to achieve effective pathogen control in Arabidopsis plants capable of SAR but not in plants with impaired signal transduction pathways. Salicylicacid-dependent plant defense apparently mediates fungicide action and efficacy in the plant. Our results using a different host-pathogen system are consistent with these observations. From our results, it also appears that the combination of fungicides and SAR as induced by ASM can result in increased efficacy against disease even at lower SAR activator concentrations not effective when applied alone. 
Perez et al. (11) did not report efficacy of ASM at rates of $17.5 \mathrm{~g}$ a.i./ha or lower sufficient for cigar wrapper quality in Cuba, which is the rate of ASM labeled in the United States and the highest rate used in the experiments reported here. However, the blue mold pathogen was reported to be present in the Cuban experimental fields at or prior to application of the first ASM treatment 7 days after transplanting. In our experiments, the first application of ASM was applied prior to the first observation of disease on the experimental farm in all years. ASM, as an SAR inducer, requires a period of several days to accumulate pathogenesis-related proteins throughout the plant prior to initiation of the resistance response (12). The lack of significant activity at lower ASM rates may be due to infection by the pathogen prior to the initiation of resistance.

Perez et al. (11) also reported that successful blue mold control was not achieved on a susceptible tobacco cultivar but only occurred in experiments on plants with polygenic resistance. Plant resistance genes may influence the SAR response because SAR induced in barley to powdery mildew differed in lines with different resistance genes (9). In Connecticut, only blue-mold-susceptible lines are commercially grown, although resistant lines are in development. Plant resistance to the blue mold pathogen may further increase the efficacy of SAR and the interaction between SAR and fungicides, and this topic remains to be investigated.

\section{ACKNOWLEDGMENTS}

I thank J. Canepa-Morrison, S. Lamoureux, J. Preste, and R. Horvath for technical assistance and R. S. Cowles for assistance with statistical analyses.

\section{LITERATURE CITED}

1. Aylor, D. E., Taylor, G. S., and Raynor, G. S. 1982. Long-range transport of tobacco blue mold spores. Agric. Meteorol. 27:217-232.

2. Cole, D. L. 1999. The efficacy of acibenzolarS-methyl, an inducer of systemic acquired resistance against bacterial and fungal diseases of tobacco. Crop Prot. 18:267-273.

3. Csinos, A. S., Pappu, H. R., McPherson, R. M., and Stephenson, M. G. 2001. Management of Tomato spotted wilt virus in flue-cured tobacco with acibenzolar-S-methyl and imidacloprid. Plant Dis. 85:292-296.

4. Kessmann, H., Oostendorp, M., Staub, T., Goerlach, J., Friedrich, L., Lawton, K., and Ryals, J. 1996. CGA 245704, mode of action of a new plant activator. Pages 961-966 in: Brighton Crop Protection Conference-Pests and Diseases. British Crop Protection Council, Farnham, UK.

5. LaMondia, J. A. 2002. Control of blue mold in Connecticut shade tobacco with Actigard: promise and impediments. Proc. 40th Tobacco Workers' Conf. Pinehurst, NC 40:39.

6. LaMondia, J. A., and Aylor, D. E. 2001. Epi- demiology and management of a periodically introduced pathogen. Biol. Invasions 3:273282.

7. LaMondia, J. A., Ferrandino, F. J., and Incorvia Mattina, M. J. 2006. Fungicide drift from aerial and ground spray application to Connecticut shade tobacco. CAES Bull. 1003.

8. LaMondia, J. A., and Horvath, R. 2001. Evaluation and comparison of spray coverage on Connecticut cigar wrapper tobacco. Tobacco Sci. 45:1-5.

9. Martinelli, J. A., Brown, J. K. M., and Wolfe, M. S. 1993. Effects of barley genotype on in duced resistance to powdery mildew. Plant Pathol. 42:195-202.

10. Molina, A., Hunt, M. D., and Ryals, J. A. 1998 Impaired fungicide activity in plants blocked in disease resistance signal transduction. Plant Cell 10:1903-1914.

11. Perez, L., Rodriguez, M. E., Rodriguez, F., and Roson, C. 2003. Efficacy of acibenzolar-Smethyl, an inducer of systemic acquired resistance against tobacco blue mould caused by Peronospora hyoscyami f. sp. tabacina. Crop Prot. 22:405-413.

12. Vallad, G. E., and Goodman, R. M. 2004 Systemic acquired resistance and induced systemic resistance in conventional agriculture. Crop Sci. 44:1920-1934.

13. Walters, D., Walsh, D., Newton, A., and Lyon, G. 2005. Induced resistance for plant disease control: Maximizing the efficacy of resistance elicitors. Phytopathology 95:1368-1373.

14. Wiglesworth, M. D., Reuveni, M., Nesmith, W. C., Siegel, M. R., Kuc, J., and Juarez, J. 1988. Resistance of Peronospora tabacina to metalaxyl in Texas and Mexico. Plant Dis. 72:964-967. 